\title{
Absence of Polycythemia in a Child with a Unique Erythropoietin Receptor Mutation in a Family with Autosomal Dominant Primary Polycythemia
}

\author{
Robert Kralovics, Lubomir Sokol, ${ }^{\star}$ and Josef T. Prchal \\ University of Alabama at Birmingham, Division of Hematology/Oncology, Birmingham, Alabama 35294-0006; and *Louisiana State \\ University, University Medical Center, Department of Internal Medicine, Lafayette, Louisiana 70506
}

\begin{abstract}
Primary familial and congenital polycythemia (PFCP or familial erythrocytosis) is a rare proliferative disorder of erythroid progenitor cells, characterized by elevated erythrocyte mass and hemoglobin concentration, hypersensitivity of erythroid progenitors to erythropoietin (EPO), and autosomal dominant inheritance or sporadic occurrence. A number of EPO receptor (EPOR) mutations were found in subjects with PFCP; most of these mutations resulted in the truncation of the $\mathrm{COOH}$-terminal of the EPOR protein. We studied a family with autosomal dominant inheritance of PFCP in which four subjects were affected in three generations. We screened the affected individuals for EPOR gene mutations using SSCP analysis and found a C5964G mutation in exon VIII that changes tyrosine codon 426 to a translation termination codon resulting in an EPOR protein truncated by 83 amino acids. The mutant C5964G-EPOR exhibited hypersensitive EPO-dependent proliferation compared to the wild-type EPOR when tested in a murine interleukin-3-dependent myeloid cell line (FDC-P1). We also examined the segregation of the mutation with PFCP in the family and found that a child in the third generation inherited the mutation without having laboratory evidence of polycythemia. Further in vitro analysis of the erythroid progenitor cells of this affected child revealed that the progenitor cells were hypersensitive to EPO (a hallmark of PFCP) suggesting the presence of the disease at the level of progenitor cells. Failure of this child to develop polycythemia suggests the existence of as yet unidentified environmental or genetic factors that may suppress disease development. (J. Clin. Invest. 1998. 102:124-129.) Key words: polycythemia $\bullet$ erythrocytosis $\bullet$ erythropoietin $\cdot$ erythroid $\bullet$ mutation
\end{abstract}

\section{Introduction}

Primary familial and congenital polycythemia (PFCP, ${ }^{1}$ also known as familial erythrocytosis) is a rare proliferative disor-

This paper was presented in a preliminary form at the 37th Annual Meeting of the American Society of Hematology, 1-5 December 1995, in Seattle, WA.

Address correspondence to Robert Kralovics, University of Alabama, Division of Hematology/Oncology, 1900 University Blvd., THT \#513, Birmingham, AL 35294-0006. Phone: 205-934-2721; FAX: 205-934-1910; E-mail: rkralovics@bmg.bhs.uab.edu

Received for publication 22 January 1998 and accepted in revised form 23 April 1998.

J. Clin. Invest.

(C) The American Society for Clinical Investigation, Inc. 0021-9738/98/07/0124/06 \$2.00

Volume 102, Number 1, July 1998, 124-129

http://www.jci.org der of erythroid progenitor cells. This autosomal dominant (or less frequently sporadic) disorder is characterized by elevated erythrocyte mass and hemoglobin concentration, hypersensitivity of erythroid progenitors to erythropoietin (EPO) in serum containing clonogenic cultures, low serum EPO level, normal hemoglobin oxygen dissociation, and absence of progression to leukemia (1-3). EPO and EPO receptor (EPOR) genes were the first candidates in the search for the molecular defect associated with PFCP (1). So far, eight mutations (including this study) of the EPOR gene were reported (4-11). Six of these mutations resulted in truncation of the EPOR $\mathrm{COOH}$-terminal negative regulatory domain and were associated with PFCP. Truncated murine EPORs lacking the COOH-terminal negative regulatory domain exhibited increased EPO-induced proliferation in cell lines transfected with these receptors (12). This exaggerated signaling is thought to cause the increased responsiveness of erythroid progenitors to EPO seen in patients with PFCP (6).

In this study, we examined the molecular basis of polycythemia in the index family that led to the original description of the PFCP disease entity (1). In our earlier linkage studies, based on a microsatellite repeat polymorphism located in the 5' untranslated region of the EPOR gene (13), we concluded that the EPOR gene was not linked with PFCP in this family since a child in the third generation (who inherited the same EPOR gene haplotype as her affected father, uncle, and grandfather) did not show any laboratory evidence of polycythemia (14). In this study, we reexamined the family in more detail and found that the child who did not have polycythemia does have some aspects of PFCP, hence confirming the linkage of PFCP with the EPOR gene. We performed detailed screening of the EPOR gene in the affected family members and identified a unique nonsense mutation in exon VIII resulting in truncation of the EPOR protein. Analysis of the inheritance of the mutation in the family and examination of the erythroid progenitors of the affected subjects uncovered a unique, not fully understood, phenomenon by which the full phenotypic expression of an EPOR mutation may be suppressed and result in the absence of polycythemia.

\section{Methods}

Case report. The propositus (Fig. 1, pedigree I1) was found at age 56 to have elevated hemoglobin concentration. Two of his three sons also had elevated hemoglobin concentration. The propositus had extensive coronary artery disease and died of acute cerebral hemorrhage $2 \mathrm{yr}$ after the diagnosis of PFCP. He had a long history of hypertension which was well controlled on antihypertensive medication.

1. Abbreviations used in this paper: BFU-E, burst-forming unitserythroid; EPO, erythropoietin; EPOR, EPO receptor; PFCP, primary familial and congenital polycythemia; SSCP, single-strand conformational polymorphism. 


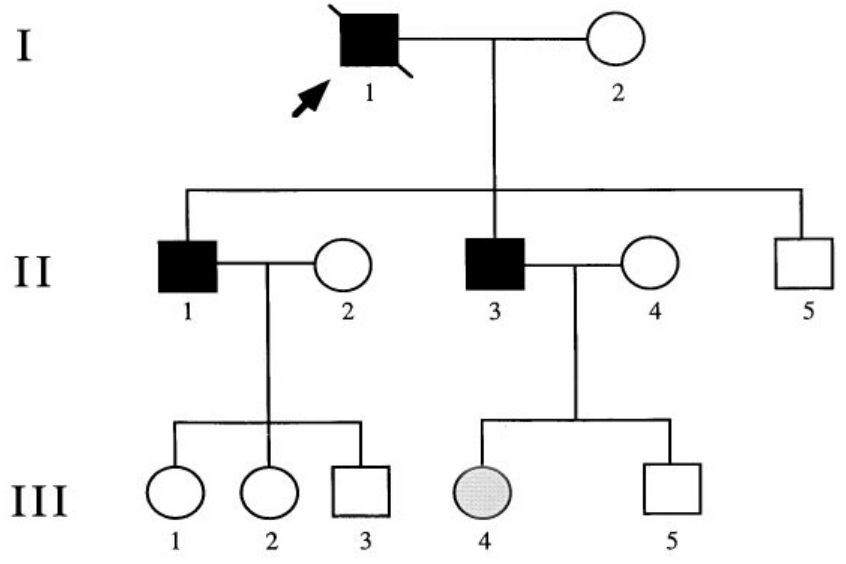

Figure 1. Pedigree of the family. The propositus is indicated with an arrow. Affected family members are indicated in black while the subject III4 (who inherited an erythropoietin receptor mutation and is nonpolycythemic) is indicated in gray.

His oldest affected son (Fig. 1, pedigree II1), now 46-yr-old, has moderate splenomegaly, hypertension for at least 12 that is well controlled with Enalapril, and coronary artery disease diagnosed $7 \mathrm{yr}$ ago. His hemoglobin concentration has been maintained within normal levels by regular phlebotomies. His serum EPO level was $4 \mathrm{mU} / \mathrm{ml}$ (normal 15-30; Table I) in 1985 determined by RIA (1). His three children (Fig. 1, pedigree IIII, IIIL, and III3), now age 13, 10, and 8 are hematologically normal. The younger affected son of the propositus (Fig. 1, pedigree II3) is now 42-yr-old and also has had severe hypertension since 1974. His hypertension has been well controlled by Atenolol. He also had one episode of deep vein thrombosis. His hemoglobin concentration has been maintained within normal levels by regular phlebotomies. His serum EPO level was low in $1985(2 \mathrm{mU} / \mathrm{ml}$ measured by RIA) (1) and normal (17 mU/ml) in 1998 (Table I). His son's (Fig. 1, pedigree III5) hemoglobin concentration has been repeatedly normal. His daughter (Fig. 1, pedigree III4) who is now 6 -yr-old was tested at ages $11 / 2,4,5$, and $6 \mathrm{yr}$ and her hemoglobin concentrations were 12.8, 12.4, 13.1, and $15.2 \mathrm{~g} / \mathrm{dl}$ (normal 12.0-16.0), respectively. A short trial of oral iron therapy has not influenced her hemoglobin concentration. Her physical examination was normal; there was no splenomegaly. Her serum EPO level was slightly decreased $(10 \mathrm{mU} / \mathrm{ml})$ in 1998 (Table I). The white blood cell count, platelet count, and red cell indices were all within normal limits for her age.

Table I. Serum Erythropoietin Levels of the Family Members Determined by Radioimmunoassay (15)

\begin{tabular}{lcc}
\hline & \multicolumn{2}{c}{ Serum EPO level (mU/ml) } \\
\cline { 2 - 3 } $\begin{array}{l}\text { Family member } \\
\text { (see pedigree) }\end{array}$ & $1985(1)$ & 1998 \\
\hline II1 & 4 & nd \\
II3 & 2 & 17 \\
II4 & nd & 22 \\
II5 & 40 & nd \\
III4 & nd & 10 \\
III5 & nd & 16 \\
& & \\
\hline
\end{tabular}

Normal range: $15-30 \mathrm{mU} / \mathrm{ml}$ (nd, not determined).
DNA, oligonucleotides, PCR. Genomic DNA was extracted from peripheral blood lymphocytes according to standard procedures (16). Template for single-strand conformational polymorphism (SSCP) analysis was prepared by PCR using primers described elsewhere (4), which were complementary to the EPOR gene in exon VIII, coding for the cytoplasmic domain of the receptor. Two pairs of primers were used for the 5'-portion of exon VIII EPOR2-FOR 5'-GAGGACCCACCTGCTTCC-3' (position 5659-5676 bp) and EPOR2-REV 5'-CAAAGCTGGCAGCAGAGG-3' (position 5942-5959 bp); the $3^{\prime}$-portion of exon VIII was amplified using primers EPOR3-FOR 5'-TCCTGCTCATCTGCTTTGG-3' (position 5899-5917 bp) and EPOR3-REV 5'-CATCTGCAGCCTGGTGTCC-3' (position 6213$6231 \mathrm{bp}$ ). PCR was performed in $50-\mu l$ reactions containing $20 \mathrm{mM}$ Tris-HCl pH 8.4, $50 \mathrm{mM} \mathrm{KCl}, 1.5 \mathrm{mM} \mathrm{MgCl}, 100 \mu \mathrm{M}$ dNTP, 300-nM primers, and $2.5 \mathrm{U} /$ reaction Taq DNA polymerase (Life Technologies, Grand Island, NY) overlaid with a drop of mineral oil (Sigma Chemical Co., St. Louis, MO). 30 cycles were performed in a thermocycler (480; Perkin-Elmer, Norwalk, CT) with the following parameters: $1 \mathrm{~min}$ at $94^{\circ} \mathrm{C}$ initial denaturation, and cycling $30 \mathrm{~s}$ at $94^{\circ} \mathrm{C}$, $30 \mathrm{~s}$ at $60^{\circ} \mathrm{C}$, and $30 \mathrm{~s}$ at $72^{\circ} \mathrm{C}$.

SSCP screening and sequence analysis. SSCP analysis was performed to detect mutations in exon VIII of the EPOR gene. The PCR products were digested with restriction enzymes to generate fragments of 150-200 bp for which the SSCP analysis has the greatest detection power (17). The 303-bp PCR product derived from the 5'-portion of exon VIII was cleaved with AvaII, BanII, and SphI restriction enzymes. The full length PCR product and the restriction fragments were analyzed on SSCP gels. The 333-bp PCR product of the 3'-portion of exon VIII was digested with AvaII, HaeIII, HinfI, RsaI, BstNI, and loaded on a 6,8 , or $12 \%$ native polyacrylamide gel (depending on the analyzed fragment size) containing $5 \%$ (vol/vol) glycerol in $0.5 \times$ Tris-borate-EDTA buffer. The gels were run at $22-25 \mathrm{~V} / \mathrm{cm}$ at $15^{\circ} \mathrm{C}$ using $15 \times 15-\mathrm{cm}$ gels in a SE600 electrophoresis apparatus (Hoeffer Scientific Instruments, San Francisco, CA). The DNA was visualized by silver staining according to standard procedures (15). The PCR product showing anomalous migration were cloned using a TA Cloning Kit (Invitrogen Corp., San Diego, CA) and sequenced using the Sequenase 2.0 kit (USB, Cleveland, $\mathrm{OH}$ ) according to manufacturer's recommendations.

In vitro BFU-E colony assay. Peripheral blood mononuclear cells from affected family members and a normal control were isolated on Ficol-Hypaque (Sigma Chemical Co.) density gradient (1.077 grams $/ \mathrm{ml}$ ). Erythropoiesis was examined by in vitro cultures as described elsewhere $(1,3)$ with the following modifications: mononuclear cells were cultured at final concentration of $2 \times 10^{5}$ cells $/ \mathrm{ml}$ in Methocult H-4531 medium (StemCell Technologies Inc., Vancouver, Canada) in 35-mM Petri dishes in the presence of $0,30,60,125,250,500,1,000$, and 3,000 $\mathrm{mU} / \mathrm{ml}$ EPO. Cultures were maintained in a humidified atmosphere of $5 \%$ carbon dioxide at $37^{\circ} \mathrm{C}$. Erythroid colonies were scored at $14 \mathrm{~d}$ by standard criteria $(18,19)$.

Cell line, plasmid constructs, proliferation assay. FDC-P1 mouse myeloid cell line (kind gift of Dr. W.S. May, Sealy Center for Oncology and Hematology, Galveston, TX) were maintained in RPMI1640 medium (Life Technologies) supplemented with $10 \%$ fetal calf serum and $2 \mathrm{ng} / \mathrm{ml}$ mouse interleukin-3 (mIL-3) (Genzyme Corp., Cambridge, MA). The wild-type human EPOR cDNA (6) was subcloned to the mammalian expression vector pCEP-4 (Invitrogen Corp.). The EPOR mutation found in the family was introduced to the pCEP-4/wild-type EPOR cDNA construct by exchanging the exon VIII SphI-PstI restriction fragment amplified out from the genomic DNA of the patient using PCR with Pfu DNA polymerase (Stratagene, La Jolla, CA) according to the manufacturer's recommendations. The presence of the mutation and the sequence of the exchanged restriction fragment were verified by nucleotide sequence analysis. $10 \mu \mathrm{g}$ of plasmid DNA was used for single electroporation (Gene Pulser apparatus; Bio-Rad Laboratories, Hercules, CA) of $10^{7}$ FDC-P1 cells in $0.8 \mathrm{ml}$ of PBS. After recovery of $48 \mathrm{~h}$, the transfected cells were transferred into medium supplemented with increasing 
concentrations (400-800 $\mu \mathrm{g} / \mathrm{ml}$ ) of Hygromycin (Sigma Chemical Co.) and the cells were cultured for a period of $3 \mathrm{wk}$. Exponentially growing selected transfected cells were washed with PBS and deprived of growth factors for $18 \mathrm{~h}$. To estimate the EPO-induced proliferation, the cells were further cultured in RPMI-1640 supplemented with $10 \%$ fetal calf serum at a density of $3 \times 10^{5} \mathrm{cells} / \mathrm{ml}$ in the presence of either $2 \mathrm{ng} / \mathrm{ml} \mathrm{mIL-} 3$ or variable EPO concentrations $(0.1-1,000 \mathrm{mU} / \mathrm{ml})$. After $48 \mathrm{~h}$, the proliferation of the cells was evaluated using an Alamar blue proliferation assay (Alamar Inc., Sacramento, CA) as recommended by the manufacturer. Briefly, $100 \mu \mathrm{l}$ of Alamar blue solution was added to $900 \mu \mathrm{l}$ of growing cells and incubated for $6 \mathrm{~h}$. Reduction of the substrate was determined by optical density measurement at 570 and $600 \mathrm{~nm}$. Dose-response curves were plotted for cells grown in the presence of EPO as a percentage of maximal cell growth measured in control samples grown at $2 \mathrm{ng} / \mathrm{ml}$ mIL-3.

\section{Results}

SSCP screening and sequence analysis of the EPOR gene. PCR products of exon VIII amplified from the genomic DNA of an affected family member (II3) and a normal control were analyzed for mutations using SSCP. Analysis of the restriction fragments on a native polyacrylamide gel revealed an aberrant mobility of HeaIII and HinfI fragments of the PCR product derived from the $3^{\prime}$-portion of exon VIII indicating a possible mutation in the region (data not shown). Sequence analysis of the PCR product revealed a $\mathrm{C}$ to $\mathrm{G}$ substitution at position 5964 of the EPOR gene (Fig. 2). The nucleotide substitution changed the tyrosine codon 426 to a termination codon resulting in a truncated EPOR with 83 amino acids missing from the $\mathrm{COOH}$-terminal of the protein.

Functional analysis of the mutant C5964G-EPOR in FDCP1 cells. The ability of the truncated mutant EPOR (C5964GEPOR) to induce proliferation was examined in IL-3-dependent mouse myeloid cell line FDC-P1 transfected with a plasmid construct allowing stable episomal expression of the receptor in these cells. The EPO-dependent proliferation of FDC-P1 cells expressing the wild-type EPOR (WT-EPOR) was compared to the cells expressing the mutant C5964G-EPOR at

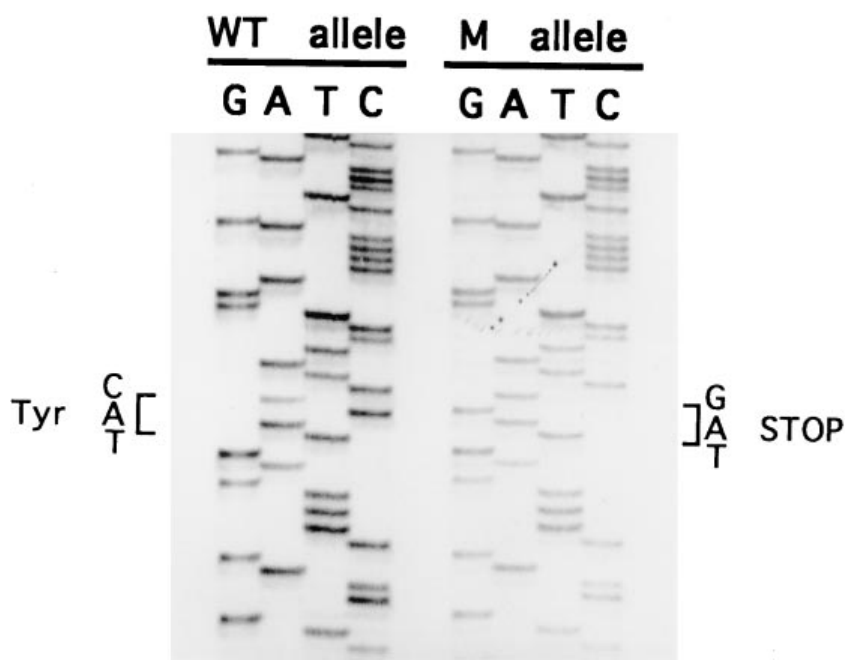

Figure 2. Sequence analysis of exon VIII of the EPOR gene. The C5964G mutation found in the affected subjects of the family is indicated ( $W T$, wild-type allele; $M$, mutant allele).

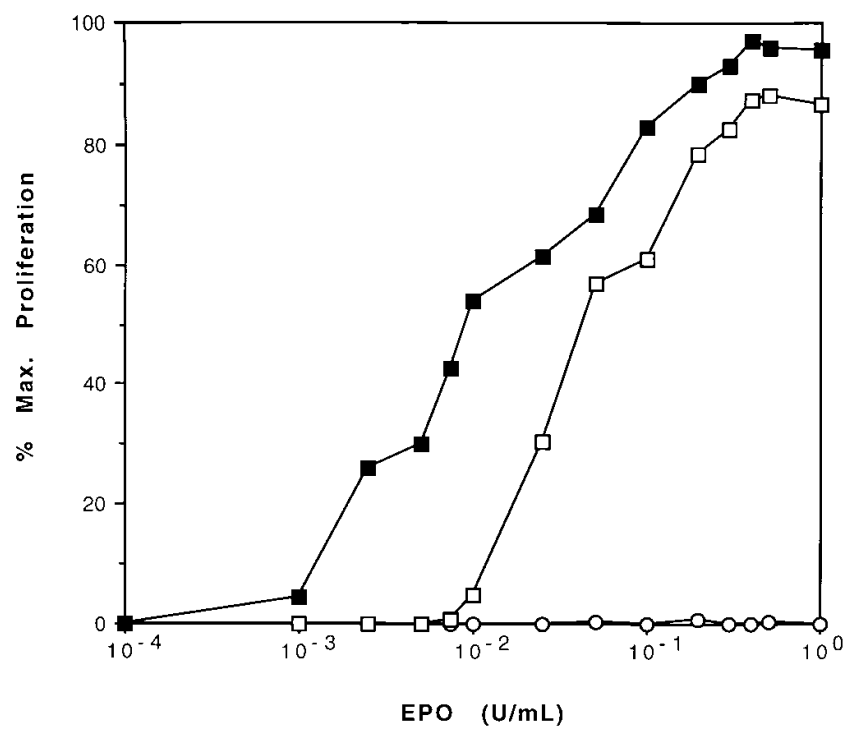

Figure 3. Functional analysis of the C5964G-EPOR mutation in murine FDC-P1 cells. The mutant C5964G-EPOR (filled square) as well as the wild-type EPOR (open square), and the pCEP-4 cloning vector without insert (open circle) were transfected to FDC-P1 cells. The EPO-dependent proliferation (at 0.1-1,000 mU/ml EPO) was examined and it is shown as percentage of maximum proliferation of cells at $2 \mathrm{ng} / \mathrm{ml}$ murine IL-3. Significant hypersensitivity to EPO stimulation is apparent in cells expressing the C5964G-EPOR compared to the wild-type EPOR. No proliferative response is observed in cells transfected with the pCEP-4 cloning vector.

0.1-1,000 $\mathrm{mU} / \mathrm{ml}$ EPO concentrations. As shown in Fig. 3, the C5964G-EPOR expressing cells exhibited a higher proliferation rate compared to cells expressing the WT-EPOR. The C5964G-EPOR cells exhibited a hypersensitive proliferative response at $1 \mathrm{mU} / \mathrm{ml}$ EPO while the WT-EPOR cells started to show proliferation at $10 \mathrm{mU} / \mathrm{ml}$ EPO. These data indicate approximately one order of magnitude difference in the proliferation rate when the C5964G-EPOR and WT-EPOR expressing cells are compared (Fig. 3).

Analysis of linkage between the mutant EPOR gene allele and polycythemia. The $\mathrm{C} 5964 \mathrm{G}$ substitution abolishes an RsaI restriction enzyme site in the EPOR mutant allele (Fig. $4 A$ ). Cleavage of the 333-bp PCR product derived from the $3^{\prime}$-portion of exon VIII with RsaI enables the analysis of the inheritance of the mutation and its segregation with the disease phenotype in the given family. The RsaI cleavage of the C5964G mutant allele results in the appearance of a 148-bp restriction fragment in the two affected sons of the propositus (pedigree II1, II3) indicating the presence of both the wild-type and the mutant EPOR alleles in these subjects (Fig. 4 B). The propositus' 6-yr-old granddaughter (pedigree III4), who appeared to be clinically normal, also inherited the mutant EPOR allele from her affected father, while her brother (III5) inherited the wild-type EPOR alleles (Fig. $4 \mathrm{~B}$ ). The absence of polycythemia in this child raised the question of linkage between the EPOR mutation and PFCP in this family and prompted us to obtain additional clinical information on this child, since her polycythemia may be manifested at a later age or suppressed by other factors. 
A

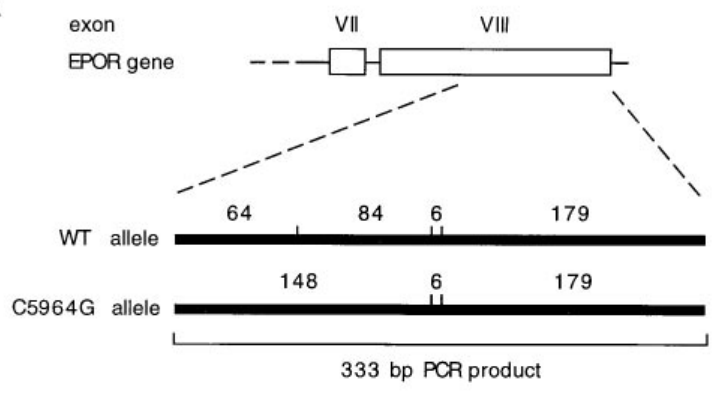

B

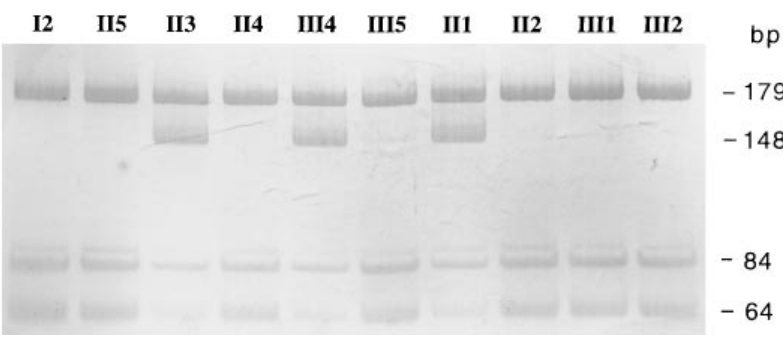

Figure 4. Analysis of the inheritance of the C5964G mutation. The C5964G mutation abolishes an RsaI restriction enzyme site in the EPOR gene, enabling analysis of the inheritance of the mutant EPOR allele in this family $(A)$. The mutant EPOR allele is detected by the appearance of a 148-bp restriction fragment. Subjects II1, II3, and III4 have the mutant C5964G allele in addition to the wild-type EPOR allele $(B)$.

EPO dose response of BFU-Es. The presence of an EPOR mutation without laboratory evidence of polycythemia in the child with the C5964G EPOR mutation (III4) led us to examine the EPO-dependent proliferation of erythroid progenitors (BFU-Es) in this subject, her affected father (II3), and her nonaffected brother (III5) in clonogenic methylcellulose cultures containing serum. The erythroid progenitors of the nonpolycythemic child with the C5964G mutation (III4), and her affected father (II3), exhibited hypersensitivity to EPO compared to the progenitors of her healthy brother (III5). The EPO response of the progenitors of these subjects was determined at least three times in the past $2 \mathrm{yr}$ in independent experiments and the observed EPO hypersensitivity of BFU-Es was always present (data not shown). This finding demonstrates the presence of the disease in the subjects with the mutant C5964G-EPOR at the level of progenitor cells (Fig. 5).

\section{Discussion}

This family and an additional family were previously studied for the presence of linkage between PFCP and the EPOR gene (14) using two microsatellite repeat polymorphisms located in the 5'-untranslated region of the EPOR gene (13). Since the child with no laboratory evidence of polycythemia (III4) inherited the same allele of the EPOR gene as her affected relatives (her father, II3; her uncle, II1; and her grandfather, the propositus, I1), the conclusion was made that the EPOR gene was not linked with PFCP and that a gene other than EPOR must be responsible for the disease in this particular family (14). In this study, we demonstrate that this child (III4) appears to have some aspects of PFCP (see below), and therefore she cannot be considered to be an unaffected individual even though she is nonpolycythemic. In light of these new findings, linkage of PFCP and the EPOR gene is established in this family. Kan and Dozy (20) first demonstrated linkage between a DNA polymorphism and a human disease. Demonstration of DNA polymorphism/disease phenotype linkages has enormously advanced our knowledge of the molecular basis of human diseases. This study points to the possibility of an erroneous conclusion deriving from such a linkage study if the disease phenotype is not clearly defined.

In this report, we describe a unique EPOR mutation in a family with autosomal dominant inheritance of PFCP. The disease phenotype is associated with a $\mathrm{C}$ to $\mathrm{G}$ substitution at position 5964 of the EPOR gene exon VIII. The mutation changes the tyrosine 426 codon (tyrosine $402, \mathrm{Y}^{402}$, of the mature EPOR protein without the leader sequence) to a termination codon which results in an EPOR protein truncated by 83 $\mathrm{COOH}$-terminal amino acids. This is the most severely truncated EPOR associated with PFCP described so far and results in a receptor lacking seven $\mathrm{COOH}$-terminal tyrosine residues normally present in the mature human EPOR protein $\left(\mathrm{Y}^{402}\right.$, $\mathrm{Y}^{430}, \mathrm{Y}^{432}, \mathrm{Y}^{444}, \mathrm{Y}^{461}, \mathrm{Y}^{465}$, and $\mathrm{Y}^{480}$ ). The majority (six out of eight) of reported EPOR mutations result in truncations of the receptor and are found in exon VIII of the EPOR gene. Only these truncation mutations were associated with PFCP (Table II); the other two described mutations are missense mutations

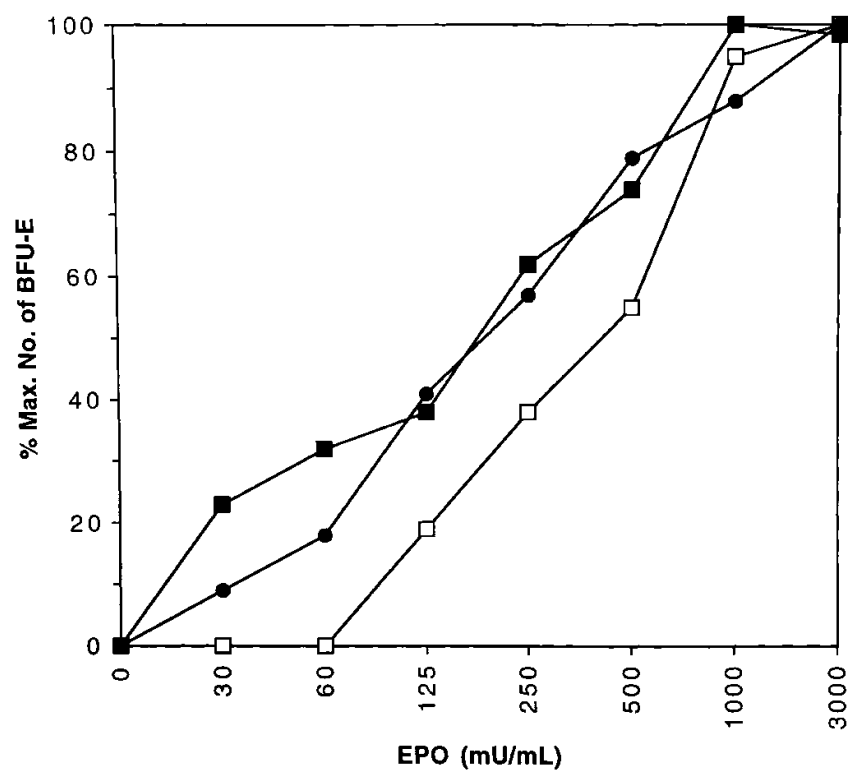

Figure 5. In vitro studies of erythroid progenitor cells. EPO dose responses of the erythroid progenitors (BFU-Es) of subject II3 (see pedigree Fig. 1; filled square), his daughter (pedigree III4; filled circle), and his healthy son (III5; open square) were determined in clonogenic cultures containing serum. The erythroid progenitors of subjects II 3 and III 4 exhibit hypersensitive proliferative response to EPO compared to the nonpolycythemic subject III5 without the EPOR mutation who served as a normal control. Erythroid (BFU-E) colonies grown at increasing EPO concentrations were counted at day 14. 


\begin{tabular}{|c|c|c|c|c|}
\hline $\begin{array}{c}\text { Mutation } \\
\text { (genomic position) }\end{array}$ & Type of mutation & Structural defect & Association with PFCP & Reference \\
\hline G6002A & nonsense & Trp439 $\rightarrow$ ter truncation & yes & 4,21 \\
\hline C6148T & substitution & Pro $488 \rightarrow$ Ser & no & 5,11 \\
\hline 5974insG & $\mathrm{G}$ insertion & frameshift $\rightarrow$ ter truncation & yes & 6 \\
\hline A6146G & substitution & Asn $487 \rightarrow$ Ser & no & 7 \\
\hline C5986T & nonsense & Gln $435 \rightarrow$ ter truncation & yes & 10 \\
\hline 5967insT & $\mathrm{T}$ insertion & frameshift $\rightarrow$ ter truncation & yes & 8 \\
\hline del5985-5991 & 7-bp deletion & frameshift $\rightarrow$ ter truncation & yes & 8,31 \\
\hline C5964G & nonsense & Tyr426 $\rightarrow$ ter truncation & yes & this study \\
\hline
\end{tabular}

ter, termination codon.

and were not shown to be linked with $\operatorname{PFCP}(5,7,11)$. The $\mathrm{COOH}$-terminal cytoplasmic portion of the EPOR contains a negative regulatory domain (12). Recent studies showed that this domain contains the binding site for SHP-1 phosphatase, which negatively regulates EPOR signaling: SHP-1 binds to phosphorylated murine $\mathrm{Y}^{429}$ (analogous to human $\mathrm{Y}^{430}$ ), dephosphorylates Janus kinase 2, and leads to the termination of the proliferative signal (22). The crucial negative regulatory function of SHP-1 in the EPOR signaling was also demonstrated in studies of mice lacking SHP-1 phosphatase (23). Therefore, truncations in this region of the EPOR result in an abnormal receptor lacking a downregulatory mechanism (very likely mediated through SHP-1) that is responsible for the hypersensitive signaling of the EPOR in erythroid progenitors of PFCP subjects. In addition, several other important binding sites are missing from these truncated receptors such as interaction sites for SHP-2 (or Syp) (24), Grb2 (25), and phosphatidylinositol 3-kinase (26). Impaired function of all these signaling elements may have significant biological effects not only at the level of erythroid progenitor cells but also in other tissues (27-30), leading to the clinical phenotype observed in PFCP subjects.

Truncated EPORs were shown to induce increased proliferative responses to EPO in myeloid cell lines transfected with these receptors $(12,6,31)$. We tested the C5964G-EPOR in the murine IL-3-dependent myeloid cell line FDC-P1 and showed that cells expressing the mutant C5964G-EPOR exhibit increased proliferation (approximately by one order of magnitude) compared to the wild-type EPOR when stimulated with EPO. These results demonstrate that the EPOR mutation found in this family likely accounts for the EPO hypersensitivity of erythroid progenitors observed in the family members who inherited the mutant EPOR gene allele.

When we examined the family for linkage between the PFCP phenotype and the C5964G EPOR mutation using RsaI restriction enzyme analysis, a child in the third generation (who appeared to be nonaffected; pedigree III4) was shown to have inherited the mutant EPOR allele from her affected father. We found that the erythroid progenitors of this nonpolycythemic child bearing the EPOR mutation and those of her affected father exhibited in vitro hypersensitivity to EPO, a condition consistent with the diagnosis of PFCP. The hypersensitive response of their erythroid pregenitors to EPO stimulation was very similar to those seen in other PFCP cases with BFU-E colonies formed at low (between 0 and $60 \mathrm{mU} / \mathrm{ml}$ )
EPO concentrations $(3,5-8,11,31,32)$. These results suggested that the progenitor cells of this child are affected by the EPOR mutation, although not clinically manifested as polycythemia. This suppression of polycythemia may be due to other unidentified environmental or genetic factors (present either in the hematopoietic progenitors but not detected under the conditions used in our in vitro experiments, in the bone marrow microenvironment, or in the serum of the subject). One possible mechanism of compensation of the red blood cell production is decreased renal EPO release. This may be reflected in the child's slightly decreased serum EPO level (10 $\mathrm{mU} / \mathrm{ml}$ ). Even though the child's lower EPO level does not seem to be significant, it may have a negative effect on her erythrocyte production that may compensate the hypersensitivity of her erythroid progenitors. This possibility may be examined in future by long-term monitoring of her serum EPO level to see if it stays low or fluctuates. It should be noted that the child's father and her uncle both had low EPO levels in 1985 ( 2 and $4 \mathrm{mU} / \mathrm{ml}$ ) but both had high hematocrit (1); therefore, it is unlikely that decreased serum EPO may have significant effect of red cell mass in these PFCP subjects. Another possible mechanism could be neocytolysis-selective destruction of new circulating erythrocytes observed after descent from high altitude and in astronauts (33), or the involvement of cytokines such as IGF-I, which was shown to be important in hypersensitive EPO-dependent proliferation of cells expressing truncated EPORs (34). Further studies of these polycythemia-compensating factors may be warranted and only long-range studies may answer these questions. It remains to be determined whether this suppressed polycythemia is childhood dependent (it should be noted that the child's affected father developed PFCP in the first year of life). Defining these polycythemia-compensating factors may be potentially useful in the development of future treatment strategies of polycythemias and may enhance our understanding of hematopoiesis in health and disease.

\section{Acknowledgments}

We thank Eugene Goldwasser (University of Chicago, Chicago, IL) for the assay of the serum EPO levels of the examined subjects. We also thank Yongli Guan and Lina Tze for their technical assistance, and Xylina Gregg and John Phelan for their help with the preparation of the manuscript.

This work was supported by a Veterans Administration Hospital 
Merit Grant, the United States Public Health Service, and National Institutes of Health grants No. HL-51650 and HL-50077.

\section{References}

1. Prchal, J.T., W.M. Crist, E. Goldwasser, G. Perrine, and J.F. Prchal. 1985. Autosomal dominant polycythemia. Blood. 66:1208-1214.

2. De la Chapelle, A., P. Sistonen, H. Lehvaslaiho, H. Ikkala, and E. Juvonen. 1993. Familial erythrocytosis genetically linked to erythropoietin receptor gene. Lancet. 341:82-84.

3. Emanuel, P.D., C.J. Eaves, V.C. Broudy, T. Papayannopoulou, M.R. Moore, A.D. D'Andrea, J.F. Prchal, A.C. Eaves, and J.T. Prchal. 1992. Familial and congenital polycythemia in three unrelated families. Blood. 79:3019-3030.

4. De la Chapelle, A., A.-L. Traskelin, and E. Juvonen. 1993. Truncated erythropoietin receptor causes dominantly inherited benign human erythrocytosis. Proc. Natl. Acad. Sci. USA. 90:4495-4499.

5. Sokol, L., J.F. Prchal, A.D. D'Andrea, T.A. Rado, and J.T. Prchal. 1994. Mutation in the negative regulatory element of the erythropoietin receptor gene in a case of sporadic primary polycythemia. Exp. Hematol. 22:447-453.

6. Sokol, L., M. Luhovy, Y. Guan, J.F. Prchal, G.L. Semenza, and J.T. Prchal. 1995. Primary familial polycythemia: a frameshift mutation in the erythropoietin receptor gene and increased sensitivity of erythroid progenitors to erythropoietin. Blood. 86:15-22.

7. Le Couedic, J.P., M.T. Mitjavila, J.L. Villeval, F. Feger, S. Gobert, P. Mayeux, N. Casadevall, and W. Vainchenker. 1996. Missense mutation of the erythropoietin receptor is a rare event in human erythroid malignancies. Blood. 87:1502-1511.

8. Kralovics, R., K. Indrak, T. Stopka, B.W. Berman, J.F. Prchal, and J.T. Prchal. 1997. Two new EPO receptor mutations: truncated EPO receptors are most frequently associated with primary familial and congenital polycythemias. Blood. 90:2057-2061.

9. Kralovics, R., L. Sokol, L. Tze, Y. Guan, J.F. Prchal, and J.T. Prchal. 1995. Absence of polycythemia phenotype in a child in PFCP family with EPO receptor mutation. Blood. 86:18a. (Abstr.)

10. Furukawa, T., M. Narita, M. Sakaue, T. Otsuka, T. Kuroha, M. Masuko, T. Azegami, K. Kishi, M. Takahashi, H. Utsumi, et al. 1997. Primary familial polycythaemia associated with novel point mutation in the erythropoietin receptor. Br. J. Haematol. 99:222-227.

11. Kralovics, R., L. Sokol, E. Broxson, and J.T. Prchal. 1997. The erythropoietin receptor gene is not linked with the polycythemia phenotype in a family with autosomal dominant primary polycythemia. Proc. Assoc. Am. Physicians. 109:580-585.

12. D'Andrea, A.D., A. Yoshimura, H. Youssoufian, L.I. Zon, J.-W. Koo, and H.F. Lodish. 1991. The cytoplasmic region of the erythropoietin receptor contains nonoverlapping positive and negative growth-regulatory domains. Mol. Cell. Biol. 11:1980-1987.

13. Sokol, L., and J.T. Prchal. 1994. Two microsatellite repeat polymorphisms in the EPOR gene. Hum. Mol. Genet. 3:219.

14. Sokol, L., J.F. Prchal, and J.T. Prchal. 1993. Primary familial and congenital polycythemia is a heterogeneous disorder. Lancet. 342:115-116.

15. Goldwasser, E., and J.B. Sherwood. 1981. Radioimmunoassay of erythropoietin. Br. J. Haematol. 48:359-363.

16. Sambrook, J., E.F. Fritsch, and T. Maniatis. 1989. Molecular cloning: a laboratory manual. 2nd ed. Cold Spring Harbor Laboratory Press, Cold Spring Harbor, NY.
17. Sheffield, V.C., J.S. Beck, A.E. Kwitek, D.V. Sandstrom, and E.M. Stone. 1993. The sensitivity of single-strand conformational polymorphism analysis for the detection of single base substitutions. Genomics. 16:325-332.

18. Erslev, A.J., and J. Caro. 1984. Pure erythrocytosis classified according to erythropoietin titers. Am. J. Med. 76:57-61.

19. Gregory, C.J., and A.C. Eaves. 1977. Human marrow cells capable of erythropoietic differentiation in vitro: Definition of three erythroid colony responses. Blood. 49:855-864.

20. Kan, Y.W, and A.M. Dozy. 1978. Polymorphism of DNA sequence adjacent to human beta-globin structural gene: relationship to sickle mutation. Proc. Natl. Acad. Sci. USA. 75:5631-5635.

21. Percy, M.J., M.F. McMullin, A.W. Roques, N.B. Westwood, J. Acharya, A.E. Hughes, T.R. Lappin, and T.C. Pearson. 1998. Erythrocytosis due to a mutation in the erythropoietin receptor gene. Br. J. Haematol. 100:407-410.

22. Klingmuller, U., U. Lorenz, L.C. Cantley, B.G. Neel, and H.F. Lodish. 1995. Specific recruitment of SH-PTP1 to the erythropoietin receptor causes inactivation of JAK2 and termination of proliferative signals. Cell. 80:729-738.

23. Shultz, L.D., P.A. Schweitzer, T.V. Rajan, T. Yi, J.N. Ihle, R.J. Matthews, M.L. Thomas, and D.R. Beier. 1993. Mutations at the murine motheaten locus are within the hematopoietic cell tyrosine phosphatase (Hcph) gene. Cell. 73:1445-1454.

24. Tauchi, T., G.-S. Feng, R. Shen, M. Hoatlin, G.C. Bagby, Jr., D. Kabat, L. Lu, and H.E. Broxmeyer. 1995. Involvement of SH2-containing phosphotyrosine phosphatase Syp in erythropoietin receptor signal transduction pathways. J. Biol. Chem. 270:5631-5635.

25. Songyang, Z., S.E. Shoelson, M. Chaudhuri, G. Gish, T. Pawson, W.G. Haser, F. King, T. Roberts, S. Ratnovsky, R.J. Lechleider, et al. 1993. SH2 domains recognize specific phosphopeptide sequences. Cell. 72:767-778.

26. Damen, J.E., R.L. Cutler, H. Jiao, T. Yi, and G. Krystal. 1995. Phosphorylation of tyrosine 503 in the erythropoietin receptor is essential for binding the P85 subunit of phoshatidylinositol 3-kinase and for EpR-associated PI 3-kinase activity. J. Biol. Chem. 270:23402-23408.

27. Anagnostou, A., E.S. Lee, N. Kesseimian, R. Levinson, and M. Steiner. 1990. Erythropoietin has a mitogenic and positive chemotactic effect on endothelial cells. Proc. Natl. Acad. Sci. USA. 87:5978-5982.

28. Anagnostou, A., Z. Liu, M. Steiner, K. Chin, E.S. Lee, N. Kessimian, and C.T. Noguchi. 1994. Erythropoietin receptor mRNA expression in human endothelial cells. Proc. Natl. Acad. Sci. USA. 91:3974-3978.

29. Masuda, S., M. Nagao, K. Takahata, Y. Konishi, F. Gallyas, T. Tabira, and R. Sasaki. 1993. Functional erythropoietin receptor of the cells with neural characteristics. J. Biol. Chem. 268:11208-11216.

30. Digicaylioglu, M., S. Bichet, H.H. Marti, R.H. Wegner, L.A. Rivas, C. Bauer, and M. Gassmann. 1995. Localization of specific erythropoietin binding sites in defined areas of the mouse brain. Proc. Natl. Acad. Sci. USA. 92:37173720 .

31. Arcasoy, M.O., B.A. Degar, K.W. Harris, and B.G. Forget. 1997. Familial erythrocytosis associated with a short deletion in the erythropoietin receptor gene. Blood. 89:4628-4635.

32. Juvonen, E., E. Ikkala, F. Fyhrquist, and T. Ruutu. 1991. Autosomal dominant erythrocythosis caused by increased sensitivity to erythropoietin. Blood. 78:3066-3069.

33. Alfrey, C.P., L. Rice, M.M. Udden, and T.B. Driscoll. 1997. Neocytolysis: physiological down-regulator of red-cell mass. Lancet. 349:1389-1390.

34. Damen, J.E., J. Krosl, K. Humophries, and G. Krystal. 1996. The hyperresponsiveness of cells expressing truncated EPOR is contingent upon insulinlike growth factor in fetal calf serum. Blood. 88:55a. (Abstr.) 